\title{
Genetic differentiation of Baetis alpinus Pictet (Ephemeroptera: Baetidae) in fragmented alpine streams
}

\author{
MICHAEL T. MONAGHAN*, PIET SPAAK, CHRISTOPHER T. ROBINSON \\ \& J. V. WARD \\ Department of Limnology, EAWAG/ETH, Dübendorf, Switzerland
}

\begin{abstract}
The interpretation of low $F_{\mathrm{ST}}$ values as evidence of high levels of gene flow among habitat fragments may be confounded by population genetic structures that are indicative of historical rather than present-day levels of gene flow. We examined the genetic structure of 23 populations of Baetis alpinus (Insecta: Ephemeroptera) living in alpine streams fragmented by lakes $(\approx 10000$ years old), reservoirs $(\approx 100$ years old $)$, and in nonfragmented streams, to examine if lakes act as barriers to gene flow and to investigate the temporal resolution of allozyme markers. Estimates of gene flow indicated little or no genetic divergence along four nonfragmented reference streams and across two lakes and two reservoirs $\left(F_{\mathrm{ST}}=0.004-0.041\right)$, but marked differentiation across four lakes $\left(F_{\mathrm{ST}}=0.092-0.362\right)$ and across one reservoir that was a lake enlarged by a dam $\left(F_{\mathrm{ST}}=0.075\right)$. Differentiation was unrelated to distance between fragments, but occurred only in lakes found in valleys that have been ice-free throughout the Holocene. We suggest that standing water bodies act as barriers to gene flow in B. alpinus and that low $F_{\mathrm{ST}}$ values observed between fragments separated by reservoirs do not indicate high levels of gene flow but rather show that genetic differentiation was not detectable within the first $100-1000$ years of habitat fragmentation.
\end{abstract}

Keywords: allozymes, barrier, dispersal, gene flow, heterozygosity, Pleistocene glaciation.

\section{Introduction}

Habitat fragmentation occurs at both evolutionary and ecological time scales, resulting from both natural and anthropogenic processes. Long-term, natural processes include Pleistocene climate warming and the retreat of boreal plants and animals upward to isolated mountain peaks (Brown, 1971; Templeton et al., 1990). Short-term processes of fragmentation often are human-caused, such as clearcutting of forests and urbanization. Consequences include the loss of total habitat area and isolation of fragments. Isolation can reduce dispersal among fragments, increase local extinction (Saunders et al., 1991), and lead to creation of a metapopulation (Hastings \& Harrison, 1994; Hanski, 1998).

Both simulation (Lacy, 1987) and empirical (Van Dongen et al., 1998) studies document a decrease in genetic diversity among fragmented populations, which potentially can reduce fitness and cause local extinction (Saccheri et al., 1998). Reduced genetic diversity may be

\footnotetext{
*Correspondence. E-mail: monaghan@eawag.ch
}

the result of decreased population size and decreased gene flow (Frankham, 1997), both of which reduce the effective population size. Accordingly, high vagility often is invoked to explain a lack of genetic differentiation among fragmented populations (e.g. Stangel et al., 1992; Hickerson \& Wolf, 1998; Ramirez \& Haakonsen, 1999).

The multiple time scales over which fragmentation occurs potentially can confound the interpretation of population genetic structure because current population genetic structure may not reflect current levels of gene flow (Larson et al., 1984; Bossart \& Prowell, 1998). Much habitat fragmentation is human-caused and therefore relatively recent, occurring at time scales of tens to hundreds of years. Studies of recent fragmentation that detect no differentiation and postulate high levels of gene flow (e.g. studies cited above) may be observing the genetic signature resulting from historical rather than current levels of gene flow. This is because genetic drift may be too slow to result in detectable differentiation among populations in landscapes recently altered by humans. Such temporal resolution of genetic markers is of general importance to population 
genetics and requires further investigation (Bossart \& Prowell, 1998).

Alpine streams provide a good opportunity to examine different time scales at which differentiation may be observed in the genetic signature of fragmented populations. Alpine streams often are fragmented by the presence of lakes or reservoirs that may act as barriers to gene flow, as these standing water habitats are unsuitable for most organisms adapted to running water. Many alpine lakes were formed following glacier retreat at the end of the Pleistocene (i.e. 1000s to 10000 years ago), while most reservoirs were constructed for hydroelectric power generation in the 20th century (e.g. 10s to 100 years ago). As such, fragments of different age are produced by similar processes. For stream insects, gene flow is achieved via larval drift (downstream transport with the current) and adult flight after emergence from the water. The fragmentation of streams by standing water may restrict downstream larval drift, upstream adult flight, or both. The result can be the genetic differentiation of populations upstream and downstream of standing water bodies. Alternatively, gene flow may be inversely related to the distance animals must travel, resulting in a positive relationship between genetic differentiation and distance between fragments.

We used allozyme electrophoresis to investigate population genetic structure of the mayfly, Baetis alpinus Pictet 1843 (Ephemeroptera: Baetidae), in alpine streams in Switzerland. We first examined whether genetic diversity was reduced in fragmented populations relative to populations living in nonfragmented streams. We then analysed whether lakes and reservoirs fragment populations and act as barriers to gene flow in a stream insect, with a focus on how habitat fragmentation at various temporal scales may be reflected by genetic population structure. Our primary hypothesis was that genetic differentiation would be evident at only evolutionary time scales, i.e. would occur between populations separated by lakes but not between populations separated by reservoirs. Our alternative hypothesis was that gene flow was reduced between fragments separated by greater distances, regardless of time since fragmentation.

\section{Materials and methods}

\section{Study sites}

Fragmentation was studied at 13 headwater sites of the Rhine, Inn, and Ticino Rivers in the Swiss Alps (Fig. 1). Each site consisted of paired sampling locations upstream and downstream of a potential dispersal barrier (i.e. lake or reservoir) or at comparable distances along a nonfragmented reference stream (Fig. 1). Six streams were fragmented by a natural lake and three streams were fragmented by reservoirs (Table 1). One of the reservoirs (Ritom) is a natural lake that has been enlarged by a dam (Knoll-Heinz, 1991). Four study sites were nonfragmented alpine streams.

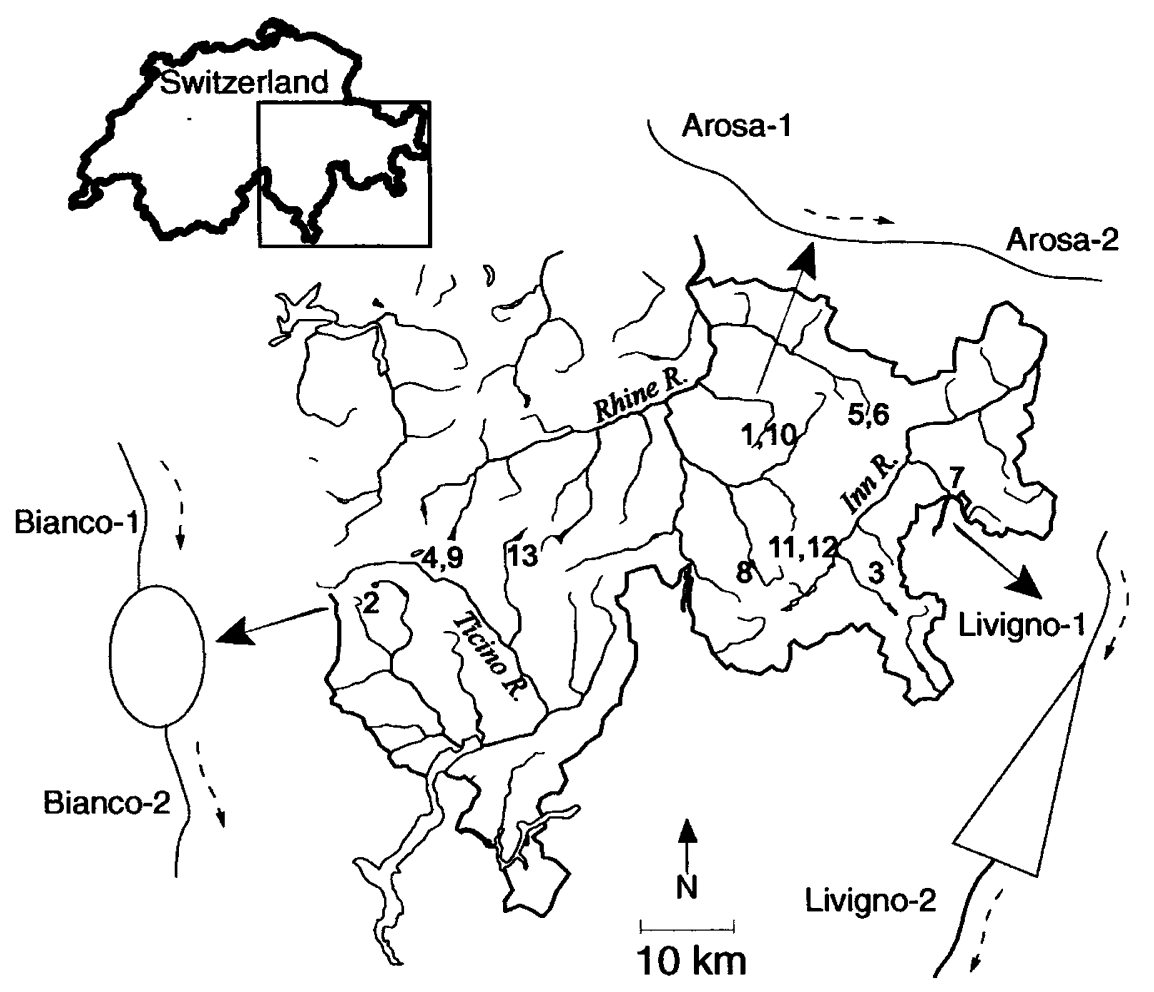

Fig. 1 Map of the study sites in Switzerland and schematics of the paired sampling design for lakes (oval), reservoirs (triangle), and nonfragmented streams (line). Dashed arrows indicate direction of water flow. Sites are designated as: 1-Schwellisee, 2-Bianco, 3-Minor, 4-Cadagno, 5-Upper Jörisee, 6-Lower Jörisee, 7-Livigno, 8-Marmorera, 9-Ritom, 10-Arosa, 11-Julierpass, 12-Silvaplana, 13-San Bernadino. 
Table 1 The 13 study sites examined in the present study. Each site consists of paired sampling locations upstream and downstream of the fragmenting feature or along the nonfragmented reference stream. Lake and reservoir names are from maps. Reference streams were unnamed and therefore designated by location

\begin{tabular}{lccc}
\hline Study site & $\begin{array}{c}\text { Distance } \\
\text { between } \\
\text { fragments (m) }\end{array}$ & $\begin{array}{c}\text { Elevation of } \\
\text { upper } \\
\text { location (m) }\end{array}$ & $\begin{array}{c}\text { Elevation change } \\
\text { between } \\
\text { fragments (m) }\end{array}$ \\
\hline Lakes & & & \\
Schwellisee & 350 & 1935 & 5 \\
Lago Bianco & 525 & 2080 & 4 \\
Puox Minor & 375 & 2340 & 15 \\
Lago Cadagno & 1075 & 1940 & 40 \\
Upper Jörisee & 550 & 2525 & 30 \\
Lower Jörisee & 975 & 2495 & 175 \\
Reservoirs & & & 155 \\
Livigno & 10 & 1910 & 250 \\
Marmorera & 7750 & 1700 & 120 \\
Ritom & 4500 & 1900 & 10 \\
Nonfragmented streams & & & 105 \\
Arosa & 375 & 1940 & 220 \\
Julierpass & 625 & 2310 & 25 \\
Silvaplana & 3225 & 2310 & \\
San Bernadino Pass & 280 & 2225 & \\
\hline
\end{tabular}

For clearer presentation of results, upstream sampling locations at each site are designated with a 1 and downstream locations a 2 (e.g. Cadagno-1 and Cadagno-2 are upstream and downstream of Lake Cadagno, respectively). Three sampling locations were shared by multiple study sites and thus used in two separate analyses: Cadagno-2 occurred between Lake Cadagno and the reservoir Ritom, and Upper Jörisee-2 occurred between the upper and lower Jörisee lakes. The third location (Julierpass-1) was used for comparison along both a short reference reach (Julierpass) and a long reference reach (Silvaplana) by pairing it with two different downstream sampling locations. Upstream sample locations ranged in elevation from 1700 to $2525 \mathrm{~m}$ a.s.1., with all but four locations occurring above $1900 \mathrm{~m}$ a.s.l. (Table 1). Water-surface distance between fragments ranged from 280 to $10000 \mathrm{~m}$ and elevation difference between fragment locations ranged from 4 to $250 \mathrm{~m}$ (Table 1).

\section{Study animal}

The mayfly Baetis alpinus is a widespread and abundant alpine species (Humpesch, 1979; Breitenmoser-Würsten \& Sartori, 1995) occurring in 1 st to 4 th order streams between 200 and $2600 \mathrm{~m}$ in elevation that do not exceed $20^{\circ} \mathrm{C}$ (Sartori \& Landolt, 1999). The life cycle of B. alpinus is quite plastic and is dependent largely upon environmental conditions, namely temperature and elevation. Humpesch (1979) observed a bivoltine life cycle in streams at $615 \mathrm{~m}$ and a univoltine life cycle at $1355 \mathrm{~m}$ in Austria, whereas Lavandier (1988) observed a univoltine life cycle in streams at $1920 \mathrm{~m}$ and semivol- tine life cycle at $2190 \mathrm{~m}$ in France. Periods of emergence and flight typically are asynchronous and extend several months (Humpesch, 1979; Kukula, 1997). Upstream bias in adult flight has been observed in B. alpinus (Thomas, 1975; Lavandier, 1982) and Hershey et al. (1993) reported flight distances of $1.6-1.9 \mathrm{~km}$ for another species of Baetis.

\section{Field collection and allozyme electrophoresis}

Between 30 and 50 late-instar larvae were collected on a single day from each sampling location using a kicknet $(250 \mu \mathrm{m}$ mesh), kept alive for $1-2 \mathrm{~h}$ in stream water, and then flash-frozen in liquid nitrogen. In the laboratory, larvae were thawed and tentatively identified using a dissecting microscope $(60 \times)$. Head capsules then were removed and preserved in $70 \%$ ethanol solution for later final taxonomic distinction by examining the mandibles with a dissecting microscope and the maxillary palpae with a light microscope $(400 \times)$. The remainder of each animal was ground in $80 \mu \mathrm{L}$ crushing buffer ( $\mathrm{diH}_{2} \mathrm{O}, \mathrm{NADP}, \beta$-mercaptoethanol). Using cellulose acetate electrophoresis and the methods and stain recipes of Hebert \& Beaton (1989), we screened 25 enzyme systems using individuals from a subset of sampling sites to identify polymorphic loci that could be scored consistently. We found six satisfactory enzyme systems and identified 44 alleles among six presumptive loci (Table 2). The final data analysis was based on at least 25 animals from each of 23 sampling locations (all data, including sample size for each locus and allele and genotype frequencies, are available from the authors). 


\section{Data analysis}

We examined genetic diversity using the mean number of alleles per locus, percent polymorphic loci $(95 \%$ criterion), and observed and expected Hardy-Weinberg heterozygosity values $\left(H-W_{\text {obs }}\right.$ and $H-W_{\text {exp }}$, respectively). All values were calculated using GENEPOP (version 3.1d; Raymond \& Rousset, 1995). Mean number of alleles per locus, $H-W_{\exp }$ and $H-W_{\text {obs }}$ were compared between locations in fragmented $(n=16)$ and nonfrag-

Table 2 Enzyme systems, presumptive loci scored, and observed subunit structure for Baetis alpinus. Peptidase substrates were Leu-Gly-Gly, Leu-Ala, and Phe-Pro for Pep-B, C, and D, respectively. Buffer systems are those designated by Richardson et al. (1986)

\begin{tabular}{lcllc}
\hline Locus & $\begin{array}{c}\text { No. } \\
\text { alleles }\end{array}$ & $\begin{array}{c}\text { Subunit } \\
\text { structure }\end{array}$ & $\begin{array}{c}\text { E.C. } \\
\text { number }\end{array}$ & $\begin{array}{c}\text { Buffer } \\
\text { system }\end{array}$ \\
\hline$M p i$ & 9 & Monomer & 5.3 .1 .8 & A \\
Pgi & 7 & Dimer & 5.3 .1 .9 & I \\
Pgm & 5 & Monomer & 2.7 .5 .1 & I \\
Pep-B & 7 & Monomer & 3.4 .11 or 13 & I \\
Pep-C & 8 & Dimer & 3.4 .11 or 13 & I \\
Pep-D & 8 & Dimer & 3.4 .11 or 13 & I \\
\hline
\end{tabular}

mented $(n=7)$ streams using ANCOVA on all data from each locus (i.e. not mean values) with locus as the covariant. Percent polymorphic loci was compared using Student's $t$-test on transformed (arcsin square root) data. Genotype diversity was calculated using Simpson's $\left(1-\sum\left(\mathrm{p}^{2}\right)\right)$ index and also compared using Student's $t$-test. Deviations from $\mathrm{H}-\mathrm{W}$ equilibrium were examined by calculating the inbreeding coefficient $\left(F_{\mathrm{IS}}\right)$. Significant difference from zero was determined using the probability test (complete enumeration or the Markov chain method depending on the number of alleles) available in GENEPOP. A Bonferroni correction was applied to adjust the $P$-value of significance to account for the 138 tests (23 populations, six loci).

Multilocus $F_{\mathrm{ST}}$ values were computed for the paired sampling locations at each site using GENEPOP. Levels of population differentiation were determined using the ranges suggested by Hartl \& Clark (1997). We observed a large number of significant deviations from HardyWeinberg equilibrium prior to comparing population pairs (presented below), indicating that assumptions of allele neutrality (Slatkin, 1985) may not be valid. We therefore calculated two sets of $F_{\mathrm{ST}}$ values; the first was averaged over all loci and the second was calculated using only loci in $\mathrm{H}-\mathrm{W}$ equilibrium (including monomorphic loci) in both locations at a site (see Table 3).

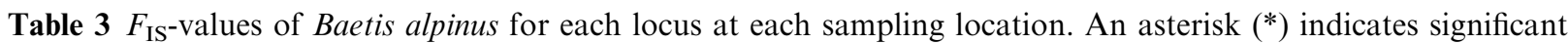
difference from zero following Bonferroni correction. A dash (-) indicates loci that were monomorphic

\begin{tabular}{lllllrr}
\hline Location & $M p i$ & PepB & PepC & PepD & Pgi & Pgm \\
\hline Schwellisee-1 & 0.176 & 0.431 & - & $0.364^{*}$ & -0.029 & -0.078 \\
Schwellisee-2 & $0.749^{*}$ & 0.287 & - & $0.891^{*}$ & -0.040 & 0.085 \\
Bianco-1 & $0.699^{*}$ & $0.531^{*}$ & - & $0.799^{*}$ & -0.051 & $0.375^{*}$ \\
Bianco-2 & $0.587^{*}$ & 0.474 & - & $0.769^{*}$ & 0.092 & $0.696^{*}$ \\
Minor-1 & 0.004 & 0.130 & - & $0.793^{*}$ & -0.068 & 0.355 \\
Minor-2 & $0.673^{*}$ & 0.165 & - & $0.715^{*}$ & -0.015 & 0.229 \\
Cadagno-1 & $0.999^{*}$ & 0.405 & $0.999^{*}$ & 0.581 & $0.607^{*}$ & $0.078^{*}$ \\
Cadagno-2 & 0.454 & 0.123 & - & $0.652^{*}$ & -0.155 & 0.054 \\
Upper Jörisee-1 & 0.573 & 0.381 & - & $0.760^{*}$ & -0.212 & 0.091 \\
Upper Jörisee-2 & -0.067 & 0.224 & -0.011 & 0.514 & 0.020 & 0.065 \\
Lower Jörisee-2 & 0.276 & $0.454^{*}$ & -0.021 & $0.639^{*}$ & 0.284 & 0.340 \\
Livigno-1 & 0.484 & 0.096 & - & 0.652 & 0.372 & 0.060 \\
Livigno-2 & $0.454^{*}$ & 0.057 & - & 0.374 & -0.005 & 0.087 \\
Marmorera-1 & 0.648 & 0.331 & - & 0.309 & 0.082 & 0.533 \\
Marmorera-2 & $0.625^{*}$ & 0.088 & $0.999^{*}$ & 0.373 & -0.203 & 0.380 \\
Ritom-2 & $0.641^{*}$ & $0.418^{*}$ & -0.062 & 0.253 & 0.042 & -0.188 \\
Arosa-1 & 0.242 & $0.718^{*}$ & -0.010 & 0.144 & 0.010 & 0.285 \\
Arosa-2 & 0.069 & $0.484^{*}$ & - & $0.566^{*}$ & -0.140 & 0.392 \\
Julierpass-1 & $0.690^{*}$ & 0.318 & - & $0.861^{*}$ & 0.053 & -0.098 \\
Julierpass-2 & $0.669^{*}$ & 0.458 & - & 0.426 & -0.115 & 0.210 \\
Silvaplana-2 & $0.513^{*}$ & 0.212 & - & $0.796^{*}$ & -0.042 & 0.414 \\
San Bernadino-1 & $0.758^{*}$ & $0.599^{*}$ & - & $0.709^{*}$ & 0.375 & 0.248 \\
San Bernadino-2 & 0.190 & $0.420^{*}$ & - & $0.583^{*}$ & 0.075 & 0.024 \\
\hline
\end{tabular}


Results of both were similar and so only the results from all six polymorphic loci are presented. Unbiased genetic distance (Nei, 1978) was estimated using BIOSYs-1 (Swofford \& Selander, 1981). We report genetic distances for each paired study site from the matrix of all pairwise comparisons.

\section{Results}

\section{Genetic diversity in fragmented and nonfragmented locations}

The mean number of alleles per locus ranged from 2.8 to 4.7 among all sampling locations (Fig. 2a) and was not significantly different between fragmented (mean $\pm 1 \mathrm{SD}: \quad 3.97 \pm 1.25$ ) and nonfragmented $\left(4.22 \pm 1.33 ;\right.$ ANCOVA; $\left.F_{1,135}=1.03, P=0.31\right)$ sample locations. Neither $H-W_{\text {exp }}$ nor $H-W_{\text {obs }}$ was significantly different between fragmented and nonfragmented locations (Fig. 2b; ANCOVA; $F_{1,135}=0.19 ; \quad P=0.66$ and $F_{1,135}=0.01, \quad P=0.76$, respectively). Mean $H-W_{\exp }$ was significantly greater than $H-W_{\text {obs }}$ at all locations (probability test; all $P$-values $<0.05$; Fig. $2 b$ ). Examined individually, 39 of 138 loci exhibited heterozygote deficiencies as indicated by significant positive $F_{\text {IS }}$ values after Bonferroni correction (Table 3). No significant differences in percentage of loci polymorphic and the Simpson's index of genotype diversity (Student's $t$-test, $P=0.65$ and 0.90 , respectively) occurred between fragmented and nonfragmented locations. All sites had

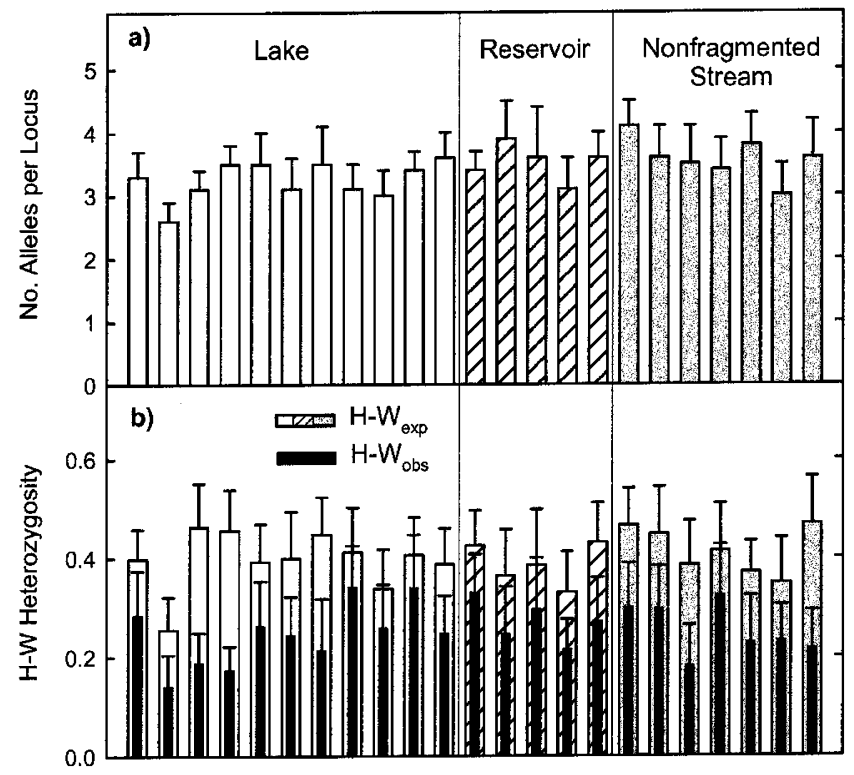

Fig. 2 Genetic diversity (based on six polymorphic loci) of Baetis alpinus in all sampling locations measured as (a) mean number of alleles per locus (error bars indicate $1 \mathrm{SD}$ ) and (b) $H-W_{\text {exp }}$ and $H-W_{\text {obs }}$ (error bars indicate $1 \mathrm{SE}$ ). genotype diversity indices greater than 0.86 ( 10 of the 22 sites has values above 0.95 ) indicating that nearly every individual within each location had a unique six-locus genotype.

\section{Genetic differentiation between fragments}

$F_{\mathrm{ST}}$ values averaged across all loci indicated moderate to substantial differentiation between the lake-fragmented locations Schwellisee, Bianco, Minor, and Cadagno $\left(F_{\mathrm{ST}}\right.$ ranged from 0.092 to 0.362 ; Fig. $\left.3 \mathrm{a}\right) . F_{\mathrm{ST}}$ values were well below 0.05 at the other two sites separated by lakes (the Upper and Lower Jörisee) indicating little or no genetic differentiation. $F_{\mathrm{ST}}$ values also indicated little or no differentiation between locations separated by the reservoirs Livigno and Marmorera, although the value at lake/reservoir Ritom $\left(F_{\mathrm{ST}}=0.075\right.$; Fig. $\left.3 \mathrm{a}\right)$ indicated significant differentiation similar to four of the lakes. $F_{\text {ST }}$ ranged from 0.004 to 0.041 in nonfragmented reference streams (Fig. 3a), implying little or no genetic differentiation.

Values of Nei's (1978) genetic distance ranged from 0.009 to 0.228 and patterns were consistent with those observed for $F_{\mathrm{ST}}$ (Fig. 3b). Specifically, the five sites exhibiting the largest genetic distance were the lakes

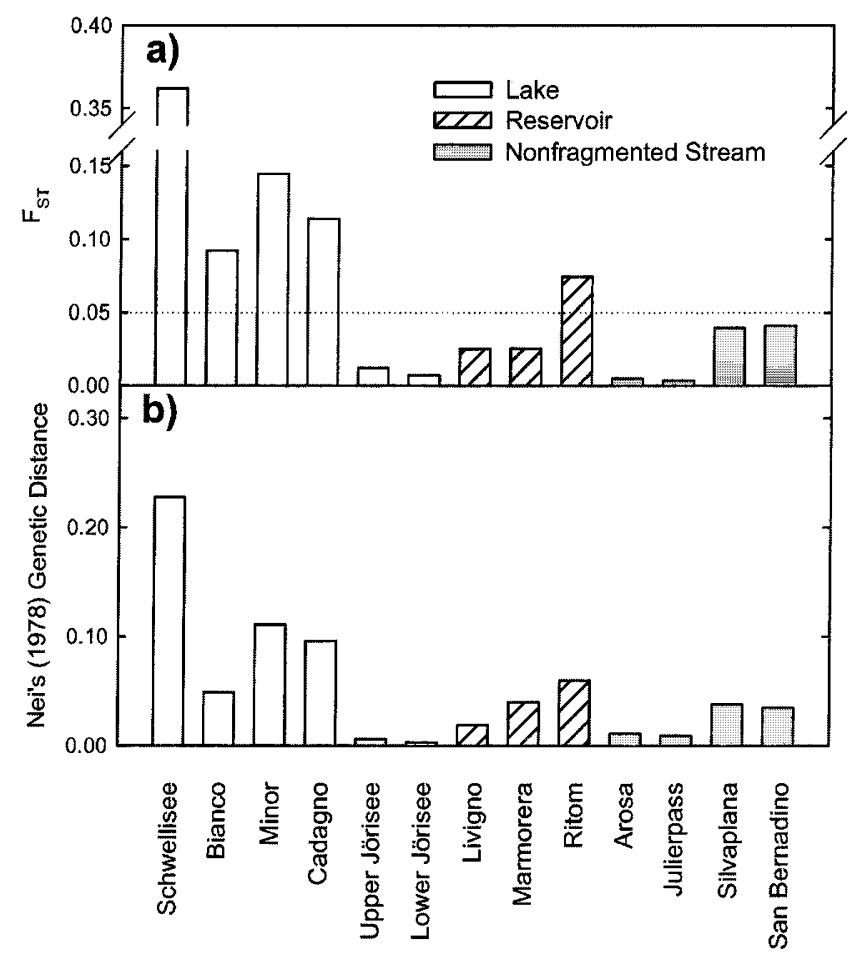

Fig. 3 Genetic differentiation between paired locations at each study site estimated using (a) $F_{\mathrm{ST}}$ averaged across all loci, and (b) Nei's (1978) unbiased genetic distance. The dotted line in (a) represents $F_{\mathrm{ST}}=0.05$, above which indicates genetic differentiation (Hartl \& Clark, 1997).

(C) The Genetics Society of Great Britain, Heredity, 86, 395-403. 


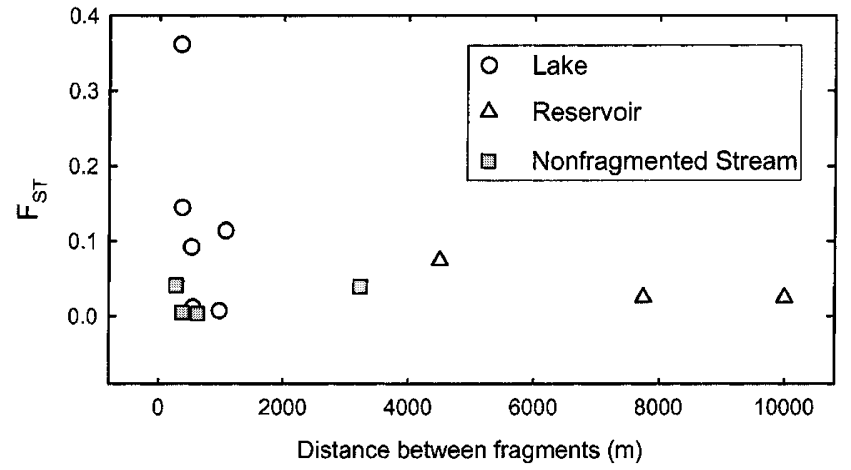

Fig. 4 Scatterplot examining the relationship between $F_{\text {ST }}$ (averaged across all loci) and geographical distance between fragments.

Schwellisee, Minor, Cadagno, Bianco, and the lake/ reservoir Ritom. The smallest genetic distance values also were observed for the lake-fragmented sites Upper and Lower Jöriseen (Fig. 3b).

No clear pattern existed between the $F_{\mathrm{ST}}$ values and distance between fragments (Fig. 4; Pearson $r=-0.25$ ). The same was true for relationships between $F_{\mathrm{ST}}$ and site elevation $(r=-0.25)$ and between $F_{\mathrm{ST}}$ and change in elevation between fragments $(r=-0.43$; neither relationship is shown).

\section{Discussion}

\section{Genetic diversity in fragmented and nonfragmented streams}

We observed no reduction in genetic diversity in populations of Baetis alpinus in fragmented relative to nonfragmented habitats. Genetic diversity in fragmented populations can be reduced first by an initial decrease in population size upon fragmentation, and further by loss of alleles due to inbreeding in small populations. Gene flow between fragments may counteract both of these processes and maintain genetic diversity (Slatkin, 1985). Based upon calculated values of $F_{\mathrm{ST}}$, gene flow was reduced among some fragments (discussed below), suggesting that large effective population sizes may maintain genetic diversity. The observed levels of inbreeding provide contradictory evidence for large populations as discussed below. Overall, genetic diversity measured with these six allozyme loci was high, with a total of 44 alleles and all $H-W_{\exp }$ values between 0.285 and 0.504 . These values of $H-W_{\exp }$ are elevated because only polymorphic loci were used in the study, but overall diversity shows that allozymes provided sufficient resolution for detecting any genetic differentiation that occurred among populations.

\section{Genetic differentiation at evolutionary and ecological time scales}

Based upon multilocus estimates of $F_{\mathrm{ST}}$ and genetic distance, we conclude that some alpine lakes act as significant barriers to gene flow for $B$. alpinus. Direct measures of dispersal of another species of Baetis indicated that a large number of adults flew 1.6$1.9 \mathrm{~km}$ upstream of the emergence site (Hershey et al., 1993). It is likely that a behavioural response of halted flight dispersal and immediate female oviposition by B. alpinus occurs when the water surface changes from flowing (the stream) to standing (the lake) (Michel Sartori, Musée cantonal de Zoologie, Lausanne, Switzerland, personal communication). Such behaviour also has been documented for other taxa of aquatic insects (Richardson \& Mackay, 1991).

Our initial hypothesis addressed evolutionary time scales and predicted that differentiation would be observed between lake-separated populations but not between reservoir-separated populations and not between locations along nonfragmented streams. We did observe marked differentiation across four lakes (Schwellisee, Bianco, Minor, and Cadagno) and little or no differentiation above and below reservoirs and in all nonfragmented reference streams in accordance with our hypothesis. However, the lowest values of $F_{\mathrm{ST}}$ observed in the study also were across lakes (Upper and Lower Jörisee). We observed differentiation $\left(F_{\mathrm{ST}}=\right.$ 0.075) across the reservoir Ritom, but the fact that Ritom was a natural lake enlarged by a dam further supports the conclusion that differentiation occurred only between sites fragmented by lakes.

The lack of a relationship between geographical distance and $F_{\mathrm{ST}}$ suggested that reduced gene flow over greater distances was not responsible for the observed patterns of $F_{\mathrm{ST}}$. Substantial differences occurred at Schwellisee where the distance between sample pairs was $350 \mathrm{~m}$, but not at Livigno where the distance was $10 \mathrm{~km}$. We also observed no relationship between genetic separation and elevation or change in elevation.

We suggest that low $F_{\mathrm{ST}}$ values at the reservoirs Livigno and Ritom resulted from the fact that fragmentation is recent and thus population differentiation is not yet detectable. Sweeney et al. (1986) observed no genetic differentiation between populations of mayflies (Ephemerella subvaria and Eurylophella verisimilis) above and below reservoirs of the Delaware River, USA. We suggest, based on our results, that this may not be indicative of current gene flow patterns, but that population differentiation has not been manifested in allele frequencies of the genetic markers. However, the lack of genetic differentiation at the two Jörisee lakes requires consideration 
of alternative hypotheses that address shorter time scales (see below).

\section{Genetic differentiation and glacial activity in the valley}

We suggest that mechanisms operating at intermediate time scales are responsible for the lack of differentiation observed at the two Jörisee lakes. The geological history of all 13 study sites is relatively similar. All of our study sites occur in valleys that were ice-covered during the last glacial maximum when snowline depression was at approximately $1300 \mathrm{~m}$. Glacial retreat occurred between 13000 and 10000 years ago and drainage networks, including lakes, began to form. In valleys where deglaciation was not complete, Holocene readvancement has occurred up to three times in the last 150-3000 years as recorded in the Aletsch and Gorner Glaciers in Switzerland (Holzhauser, 1995). This is the case in the valley containing the Jöri lakes, where the existing Jöri Glacier extended into the lower Jörisee itself during the Little Ice Age (1600-1850 AD.) (Maisch, 1992). In contrast, the valleys containing Schwellisee and Minor have been icefree since the last maximum (Maisch, 1992, 1995) indicating that the drainage systems are of the order of 10000 years old. The same is probably true for Lake Cadagno based on the lack of a glacier at present; one study documents its age at 8000 years (Deldon et al., 1998). Because Ritom is located in the same valley as Cadagno and at a lower elevation, it probably has been ice-free for a comparable amount of time. It is unclear whether Lake Bianco has been reglaciated, but the absence of a glacier at present and its south-facing aspect suggests it has been ice-free throughout the Holocene.

\section{Heterozygosity and inbreeding in Baetis alpinus}

We observed pronounced heterozygote deficiencies in the present study. Only three of 23 populations were in Hardy-Weinberg equilibrium for all loci, even after Bonferroni correction. Similar findings have been reported for another species of Baetis (Schmidt et al., 1995) as well as other stream invertebrates (Bunn \& Hughes, 1997; Hughes et al., 1998). As an explanatory mechanism, Schmidt et al. (1995) and Bunn \& Hughes (1997) proposed extinction and recolonization of local populations, specifically that populations were the result of only a few ovipositing females each generation. Even relatively conservative estimates of fecundity accounted for estimated population sizes of the streams investigated (Bunn \& Hughes, 1997). In the present study, we observed even more pronounced heterozygote deficiencies than did Schmidt et al. (1995) and Bunn \& Hughes (1997), thus presenting further evidence that sampled individuals may be offspring of only a few adult matings. The genetic examination of 25 ovipositing females within a given reach of stream would perhaps offer some explanation for this consistent pattern.

\section{Conclusions}

Our results suggest that historical rather than presentday levels of gene flow are reflected in the existing patterns of population genetic structure of Baetis alpinus (Larson et al., 1984). Without more information regarding the temporal resolution of genetic markers, we suggest caution should be taken when studies of habitat fragmentation conclude that levels of gene flow remain high. For example, if the present study had been limited to only the reservoirs, high levels of gene flow may have been invoked as the causal mechanism. We suggest, however, that low $F_{\mathrm{ST}}$ values are probably not indicative of current levels of gene flow, but rather reflect a slow rate of divergence of fragmented populations, and that the allozyme markers used were able to detect genetic isolation of populations only after $1000+$ years of reduced gene flow. Because reservoirs tend to be larger in surface area and elongate in shape (Ryding \& Rast, 1989), differentiation across reservoirs may occur at a faster rate and be even more pronounced than across lakes.

\section{Acknowledgements}

The authors especially appreciate the assistance of Mäggi Hieber during field sampling. Field and laboratory assistance also was provided by Peter Burgherr, Christine Calvino, Christa Jolidon, Sandra Lass, Florian Malard, Friederike Mösslacher, Marcos de la Puenta Nilsson, Karsten Rinke, Sven Schalla, and Bettina Wagner. Gigi Ostrow helped with field and laboratory work and provided critical comments on an early draft of the manuscript. We appreciate the help of Urs Uehlinger during study site selection and we thank Thomas Scheurer and Flurin Filli for their assistance and encouragement in the Swiss National Park. Much gratitude is owed to Christian Ohlendorf and Gerhard Mohler for their help obtaining and interpreting literature on the Quaternary geology of the study sites. Finally, we thank John Brookfield and two anonymous referees for comments that improved the manuscript. Research was funded by Swiss National Science Foundation grant no. 31-50444.97/1. 


\section{References}

BOSSART, J. L. AND PROWELL, D. P. 1998. Genetic estimates of population structure and gene flow: limitations, lessons, and new directions. Trends Ecol. Evol., 13, 202-206.

BREITENMOSER-WÜRSTEN, C. AND SARTORI, M. 1995. Distribution, diversity, life cycle and growth of a mayfly community in a prealpine stream system (Insecta, Ephemeroptera). Hydrobiologia, 308, 85-101.

BROWN, J.H. 1971. Mammals on mountaintops: Nonequilibrium insular biogeography. Am. Nat., 105, 467-478.

BUNN, S. E. AND HUGHES, J. M. 1997. Dispersal and recruitment in streams: Evidence from genetic studies. J. N. Am. Benthol. Soc., 16, 338-346.

DEldon, C., HANSElmanN, K., PEDUZZI, R. AND BACHOFEN, R. 1998. Orographical and geochemical description of the meromictic Alpine Lake Cadagno. Documenta Ist. Ital. Idrobiol., 63, 5-9.

FRANKHAM, R. 1997. Do island populations have less genetic variation than mainland populations? Heredity, $\mathbf{7 8}$, 311-327.

HANSKI, I. 1998. Metapopulation dynamics. Nature, 396, 41-49.

HARTL, D. L. AND CLARK, A. G. 1997. Principles of Population Genetics, 3rd edn. Sinauer, Sunderland MA.

HASTINGS, A. AND HARRISON, s. 1994. Metapopulation dynamics and genetics. Ann. Rev. Ecol. Syst., 25, 167-188.

HEBERT, P. D. N. AND BEATON, M. J. 1989. Methodologies for Allozyme Analysis using Cellulose Acetate Electrophoresis. Helena Laboratories, Beaumont, TX.

HERSHEY, A. E., PASTOR, J., PETERSON, B. J. AND KLING, G. W. 1993. Stable isotopes resolve the drift paradox for Baetis mayflies in an Arctic River. Ecology, 74, 2315-2325.

HiCKerson, L. L. AND WOLF, P. G. 1998. Population genetic structure of Arctomecon californica Torrey and Fremont (Papaveraceae) in fragmented and unfragmented habitat. Plant Species Biol., 13, 21-33.

HOLZHAUSER, H. 1995. Gletscherschwankungen innerhalb der letzten 3200 Jahre am Beispiel des grossen Aletsch- and des Gornergletschers. Neue Ergebnisse. In: Gletscher in ständigen Wandel: Jubiläums-Symposium der Schweizerischen Gletscherkommission 1993 Verbier (Valais, Schweiz), pp. 101-122. Hochschulverlag AG, ETH Zürich.

HUGHES, J. M., BUNN, S. E., HURWOOD, D. A. AND CLEARY, C. 1998. Dispersal and recruitment of Tasiagma ciliata (Trichoptera: Tasimiidae) in rainforest streams, south-eastern Australia. Freshwater Biol., 39, 117-127.

HUMPESCH, U. H. 1979. Life cycles and growth of Baetis spp. (Ephemeroptera: Baetidae) in the laboratory and in two stony streams in Austria. Freshwater Biol., 9, 467-479.

KNOLL-HeINZ, F. 1991. Piora: Konzept für die Erhaltung einer Landschaft. WWF Sezione Svizzera Italiano, Bellinzona.

KUKULA, K. 1997. The life cycles of three species of Ephemeroptera in two streams in Poland. Hydrobiologia, 353, 193-198.

LACY, R. C. 1987. Loss of genetic diversity from managed populations: interacting effects of drift, mutation, immigration, selection, and population subdivision. Conserv. Biol., 1, $143-158$
LARSON, A., WAKE, D. B. AND YANEV, K. P. 1984. Measuring gene flow among populations having high levels of genetic fragmentation. Genetics, 106, 293-308.

LAVANDIER, P. 1982. Evidence of upstream migration by female adults of Baetis alpinus Pict. (Ephemeroptera) at high altitude in the Pyrenees. Annls Limnol., 18, 55-59.

LAVANDIER, P. 1988. Semivoltinisme dans des populations de haute montagne de Baetis alpinus Pictet (Ephemeroptera). Bull. Soc. Hist. Nat. Toulouse, 124, 61-64.

MAISCH, M. 1992. Die Gletscher Graubündens; Habil Schrift Geograph. Inst. University of Zürich, Teil A und B. Phys. Geographie, 33.

MAISCH, M. 1995. Gletscherschwundphasen im Zeitraum des ausgehended Spätglazials (Egesen-Stadium) und seit dem Hochstand von 1850 sowie Prognosen zum künftigen Eisrückgang in den Alpen. In: Gletscher in ständigen Wandel: Jubiläums-Symposium der Schweizerischen Gletscherkommission 1993 Verbier (Valais, Schweiz), pp. 81-100 Hochschulverlag AG, ETH Zürich.

NEI, M. 1978. Estimation of average heterozygosity and genetic distance from a small number of individuals. Genetics, $\mathbf{8 9}$, 583-590.

RAMIREZ, M. G. AND HAAKONSEN, K. E. 1999. Gene flow among habitat patches on a fragmented landscape in the spider Argiope trifasciata (Araneae: Araneidae). Heredity, 83, 580-585.

RAYMOND, M. AND ROUSSET, F. 1995. GENEPOP (version 1.2): population genetics software for exact tests and ecumenicism. J. Hered., 86, 248-249.

RICHARDSON, B. J., BAVERSTOCK, P. R. AND ADAMS, M. 1986. Allozyme Electrophoresis. Academic Press, San Diego.

RICHARDSON, J. S. AND MACKAY, R. J. 1991. Lake outlets and the distribution of filter-feeders: an assessment of hypotheses. Oikos, 62, 370-380.

RYDING, S. O. AND RAST, w. 1989. The control of eutrophication of lakes and reservoirs. UNESCO, Paris.

SACCHERI, I., KUUSSAARI, M., KANKARE, M., VIKMAN, P. ET AL. 1998. Inbreeding and extinction in a butterfly metapopulation. Nature, 392, 491-494.

SARTORI, M. AND LANDOLT, P. 1999. Atlas de distribution des ephemeres de Suisse (Insecta, Ephemeroptera). Centre Suisse de Cartographie de la Faune, Neuchatel.

SAUNDERS, D. A., HOBBS, R. J. AND MARGUlES, C. R. 1991. Biological consequences of ecosystem fragmentation: a review. Conserv. Biol., 5, 18-32.

SCHMIDT, S. K., HUGHES, J. M. AND BUNN, S. E. 1995. Gene flow among conspecific populations of Baetis sp. (Ephemeroptera): adult flight and larval drift. J. N. Am. Benthol. Soc., 14, 147-157.

SLAtKin, M. 1985. Gene flow in natural populations. Ann. Rev. Ecol. Syst., 16, 393-430.

STANGEL, P. W., LENNARTZ, M. R. AND SMITH, M. H. 1992. Genetic variation and population structure of red-cockaded woodpeckers. Conserv. Biol., 6, 283-292.

SWEENEY, B. W., FUNK, D. H. AND VANNOTE, R. L. 1986. Population genetic structure of two mayflies (Ephemerella subvaria, Eurylophella versimilis) in the Delaware River drainage basin (USA). J. N. Am. Benthol. Soc., 5, 253-262. 
SWOFFORD, D. L. AND SELANDER, R. B. 1981. BIOSYS-1: $a$ FORTRAN program for the comprehensive analysis of electrophoretic data in population genetics and systematics. J. Hered., 72, 281-283.

TEMPLETON, A. R., SHAW, K., ROUTMAN, E. AND DAVIS, S. K. 1990. The genetic consequences of habitat fragmentation. Ann. Missouri Bot. Gard., 77, 13-27.
THOMAS, A. G. B. 1975. Ephéméroptères du sud-ouest de la France. I. Migrations d'imagos a haute altitude. Annls. Limnol., 11, 47-66.

VAN DONGEN, S., BACKELJAU, T., MATTHYSEN, E. AND DHONDT, A. A. 1998. Genetic population structure of the winter moth (Operophtera brumata L.) (Lepidoptera, Geometridae) in a fragmented landscape. Heredity, 80, 92-100. 